\title{
CUSTOMER CENTRICITY: KEPUASAN KONSUMEN MELALUI NILAI PELANGGAN BERDASARKAN VALUE-IN-USE TERHADAP KUALITAS PRODUK SAYUR ORGANIK (Studi kasus di Ujenk Mart Bandung, Jawa Barat)
}

\author{
Hesty Nurul Utami ${ }^{1 *}$, Anggita Chaeriyah ${ }^{2}$ \\ ${ }^{1,2}$ Program Studi Agribisnis, Fakultas Pertanian Universitas Padjajaran, Bandung, Indonesia \\ *E-mail korespondensi: hesty.nurul@unpad.ac.id
}

\begin{abstract}
ABSTRAK
Produk makanan organic saat ini menjadi popular di kalangan masyrakat dengan gaya hidup sehat. Sebagian besar produk organic dipasarkan di pasar modern seperti supermarket, speciality store, dan rantai pasar modern lainnya untuk menyediakan produk segar organic dengan berbagai macam pilihan untuk memenuhi kebutuhan dan keinginan konsumen. Penelitian ini bertujuan untuk menjelaskan pengaruh nilai pelanggan atas kualitas produk terhadap kepuasan pelanggan sayuran organik di Ujenk Mart sebagai salah satu 'local fresh market' di Kota Bandung. Metode penelitian yang digunakan adalah metode penelitian kualitatif dengan alat analisis regresi linear sederhana dan customer value mapping. Jumlah sampel sebanyak 56 responden. Hasil analisis menunjukkan bahwa nilai pelanggan mempengaruhi kepuasan pelanggan melalui indikator kualitas produk. Value-in-use konsumen melalui pengalaman mengkonsumsi produk menunjukkan nilai pelanggan pada posisi fair value antara manfaat produk melalui kualitas dengan total biaya yang harus dikeluarkan untuk menikmati produk sayuran segar organic.
\end{abstract}

Kata Kunci: Kepuasan konsumen, sayuran organink, value in use

\begin{abstract}
Organic food become more popular in the modern lifestyle. Most of the organic product especially organic fresh produce sold in the modern market chain such as supermarkets, specialty store, and other modern retail channel by providing fresh organic products with variety of choices and selection to fulfil consumer needs and wants toward fresh produce. This study objective was to explain the effect of customer value based on the value-in-use through product quality toward customer satisfaction of organic vegetables in Ujenk Mart as one of 'Local Fresh Market' in Bandung City. The research method used quantitative method with data analysis using the simple linear regression analysis and customer value mapping. Number of samples obtained were 56 respondents. Results of linear regression analysis indicates that customer value significantly influence customer satisfaction through providing product quality. Value-in-use from customer perspective on experiencing organic fresh produce quality presented a fair value between product quality benefits and overall cost.
\end{abstract}

Keywords: Consumers satisfaction, organic vegetables, value in use

\section{PENDAHULUAN}

Perubahan pola hidup masyarakat yang semakin peduli terhadap lingkungan berdampak dengan munculnya minat akan produk organik. Permintaan pasar akan produk pertanian organik pun meningkat diiringi dengan banyaknya produsen produk organik yang bermunculan. Produk pertanian organik telah memberikan peluang bagi pengembangan pertanian organik. Salah satu komoditas pertanian yang banyak dikembangkan untuk produk organik adalah komoditas sayuran. Komoditas sayuran merupakan tanaman yang paling mudah untuk dibudidayakan dengan menghasilkan produk yang baik tanpa adanya pemberian bahanbahan kimia. Selain itu sayuran juga sangat penting untuk dikonsumsi untuk kesehatan dimana sayuran merupakan sumber vitamin, mineral, protein nabati dan serat. Oleh karena 
itu, sayuran menjadi produk yang paling banyak dikembangkan untuk produk organik yang biasa dikonsumsi.

Perilaku pembelian produk - produk makanan organik seperti sayuran merupakan salah bentuk perubahan masyarakat saat ini yang mulai kembali untuk mempertimbangkan kondisi lingkungan (green buying) dengan mengkonsumsi produk - produk yang ramah lingkungan (Maineri dkk, 1997). Meskipun konsekunesi bagi konsumen atas pembelian produk - produk makanan organik adalah harga yang dibayarkan lebih tinggi dibandingkan produk makanan unorganik. Sehingga, keinginan konsumen untuk membayar produk organic menjadi salah satu indikator dari ukuran nilai produk makanan (food values) dari perspektif konsumen (Lusk, 2011).

Salah satu cara dalam memasarkan sayuran organik adalah dengan menjual produk tersebut ke pasar yang sesuai yaitu pasar modern. Maraknya supermaket, outletoutlet ataupun pasar alternarif lain di berbagai kota yang menyediakan produk segar pertanian organik menjadikan konsumen memiliki berbagai pilihan. Variasi pilihan saluran pemasaran yang dapat dipilih oleh konsumen dapat memberikan alternatif preferensi tempat berbelanja bagi konsumen, sehingga nilai suatu produk untuk kategori makanan dapat pula dilihat berdasarkan keyakinan konsumen apakah produk makanan organik memiliki perlakuan relative tertentu jika dibandingkan dengan membeli produk makanan unorganik (Lusk, 2011). Masyarakat semakin jeli dalam menentukan pilihan, didukung pula dengan banyaknya pilihan produk dan alternatif tempat pembelian sayuran organik yang bermunculan. Dengan demikian masyarakat dapat dengan mudah mencari produk organik ke pasar yang memiliki nilai yang lebih menguntungkan. Nilai pelanggan dapat dijadikan sebagai umpan balik bagi saluran pemasaran di sepanjang rantai pasok untuk menentukan strategi pemasaran melalui kesadaran konsumen terhadap indikator - indikator pemasaran (Utami dkk, 2016).

Agar pasar tetap unggul dan menjadi pilihan bagi pelanggan maka pasar tersebut harus berorientasi pada kepuasan pelanggan. Memberikan kepuasan pada pelanggan merupakan tujuan dari setiap usaha karena pelanggan dapat menentukan sikapnya terhadap produk yang ideal bagi kebutuhannya. Upaya dalam menciptakan kepuasan pelanggan dapat dilakukan dengan pengukuran nilai pelanggan. Monroe mengemukakan bahwa nilai pelanggan adalah antara persepsi pelanggan terhadap kualitas atau manfaat produk dan pengorbanan yang dilakukan lewat harga yang di bayarkan (Tjiptono, 2001). Seorang pelanggan yang puas adalah pelanggan yang merasa mendapatkan value atau nilai dari produsen atau penyedia jasa. Terciptanya kepuasan pelanggan dapat memberikan beberapa manfaat hubungan antar perusahaan dan pelanggan menjadi harmonis memberikan dasar yang baik bagi pembelian ulang dan terciptanya kepuasan pelanggan dan membentuk suatu rekomendasi dari mulut ke mulut yang menguntungkan bagi penyedia layanan (Tjiptono, 2005).

Ujenk Mart merupakan salah satu pasar modern yang memiliki konsep self-service. Konsep toko yang diusung oleh Ujenk Mart adalah specialty store dimana toko modern ini menjual barang khusus yaitu disini merupakan produk segar. Disamping itu, terdapat produk-produk lain yang disediakan di Ujenk Mart yaitu berbagai makanan, minuman, barang kebutuhan sehari-hari, hingga terdapat mini gerai makanan siap saji. Ujenk Mart ini memiliki tagline sebagai "Local Fresh Market" yang artinya toko lokal yang menyediakan produk segar terbaik yaitu seperti sayur-sayuran, buah-buahan dan berbagai macam daging yang berasal dari produk lokal maupun impor. Komoditi sayuran segar yang ditawarkan oleh Ujenk Mart pun terbagi menjadi sayuran non organik dan sayuran organik. Selain sayur-sayuran, produk lain seperti beras serta produk makanan kesehatan banyak yang disediakan dengan konsep organik. Target pasar Ujenk Mart ini merupakan konsumen akhir/end user khususnya ingin membeli produk segar asli dari Indonesia. Lokasi yang startegis menjadi salah keunggulan yang dimiliki oleh Ujenk Mart, sehingga memiliki potensi tinggi untuk mendapatkan pangsa pasar yang menguntungkan. Melalui konsep pasar produk organic, Ujenk Mart memiliki potensi dalam mengembangkan pangsa pasarnya dengan menciptakan kepuasan pelanggannya akan produk yang ditawarkan khusunya pada 
produk sayur organic yang diprediksi mulai menjadi perhatian konsumen di kota besar seperti Bandung. Sehingga focus penelitian ini adalah untuk menginvestigasi pengaruh nilai pelanggan atas kualitas produk terhadap kepuasan pelanggan dari sayuran organik.

\section{KAJIAN PUSTAKA}

\section{Pertanian Organik}

Pertanian organik adalah sistem pertanian organik yang holistik dan terpadu, yang mengoptimalkan kesehatan dan produktivitas agroekosistem secara alami, sehingga mampu menghasilkan pangan dan serat yang cukup, berkualitas dan berkelanjutan. Sementara menurut Pracaya (2006) pertanian organik adalah sistem pertanian (dalam hal bercocok tanaman) yang tidak meggunakan bahan kimia, tetapi menggunakan bahan organik. Praktek pertanian ini merupakan sistem pertanian alami berwawasan lingkungan untuk menciptakan hasil produksi yang maksimal dengan tidak menggunakan bahan-bahan kimia yang dapat merusak lingkungan.

\section{Nilai Pelanggan}

Menurut Kotler (2000) nilai pelanggan adalah selisish antara nilai pelanggan total dan biaya pelanggan total. Nilai pelanggan total yaitu sekumpulan manfaat ekonomis, fungsional, psikologis, yang diharapkan oleh pelanggan atas tawaran pasar tertentu sementara biaya pelanggan total yaitu sekumpulan biaya yang diharapkan oleh pelanggan yang dikeluarkan untuk mengevaluasi, mendapatkan, menggunakan dan membuang produk dan jasa.

Nilai pelanggan menurut Woodruff (1997) adalah persepsi dan apa yang dirasakan pelanggan dan evaluasinya terhadap atribut produk dan kinerjanya, konsekuaensi yang timbul setelah mengkonsusi produk yang pada akhirnya akan mencapai tujuannya dalam situasi pemakaian. Dari definisi tersebut dapat ditarik bahwa terdapat dua komponen utama yang menentukan nilai pelanggan yaitu: manfaat dan pengorbanan. Dimensi nilai pelanggan menurut Sweeney dan Soutar (2001):

1. Nilai emosional (Emotional value)

2. Nilai Sosial (Social Value)
3. Nilai Kualitas atau Performa Jasa (Quality/Performance Value)

4. Nilai Terhadap Biaya (Price Value) Menciptakan nilai pelanggan menjadi salah satu tugas utama aktivitas pemasaran dengan cara meningkatkan manfaat yang diterima konsumen dan menurunkan keseluruhan biaya yang harsu dikeluarkan untuk menikmati atau mengkonsumsi produk. Sehingga, tujuan utama aktivitas pemasaran adalah berupaya untuk memaksimalkan rasio relatif yang lebih menguntungkan dibandingkan dengan apa yang ditawarkan oleh pesaing (Christopher \& Peck, 1997). Terminologi value-in-use dari perspektif konsumen adalah sebagai upaya untuk menciptakan superior customer value. Valuein-use merupakan salah satu konsep menciptakan nilai bagi pelanggan berdasarkan penggunaan aktual produk tanpa hanya mengandalkan mengandalkan nilai dari hasil pertukaran produk dan harga semata atau value-in-exchange (Vargo \& Lusch, 2008). Apabila konsumen memiliki persepsi bahwa manfaat keseluruhan dari produk yang dikonsumsi dapat melebihi keselurhan biaya yang dikeluarkan untuk memperoleh produk tersebut, inilah yang disebut sebagai value-inuse (Christopher \& Peck, 1997). Sehingga pemahaman mengenai menciptakan nilai pelanggan dengan menggali pengalaman konsumen dalam menggunakan produk dapat menjadi salah satu cara untuk dapat meningkatkan persepsi pelaggan terhadap nilai suatu produk dan berpotensi untuk meningkatkan kepuasan pelanggan.

\section{Kualitas Produk}

Kualitas produk menurut Garvin (1998) dalam Tjiptono (2001) adalah suatu kondisi dinamis yang berhubungan dengan produk, manusia atau tenaga kerja, proses, serta lingkungan yang mematuhi atau melebihi harapan pelanggan atau konsumen. Dimensidimensi dari kualitas produk dalam Tjiptono (2001) mengungkapkan delapan dimensi kualitas produk yang bisa dimainkan oleh pemasar, yaitu:

1. Kinerja (Performance), yaitu fungsi utama suatu produk. Biasanya menjadi bahan pertimbangan pertama dalam memilih sebuah produk.

2. Fitur (Feature), yaitu karakteristik atau ciri-ciri tambahan yang 
melengkapi manfaat dasar bagi suatu produk.

3. Daya tahan (Durability), yaitu usia atau harapan terhadap umur produk

4. Kehandalan (Realibility), yaitu peluang suatu produk bebas dari kegagalan saat menjalani fungsinya

5. Pelayanan (Serviceability), yaitu kemampuan diperbaiki: mudah, cepat, dan kompeten.

6. Kesesuaian dengan spesifikasi (Comformance quality), yaitu kesesuaian kinerja produk dengan standar yang dinyatakan suatu produk.

7. Keindahan tampilan produk (Aesthetic), yaitu sesuatu yang menyangkut tampilan produk yang membuat pelanggan suka

8. Kualitas yang dirasakan (Perceived quality), yaitu menyangkut penilaian pelanggan terhadap reputasi produk tersebut seperti citra, merek, atau iklan

\section{Kepuasan Pelanggan}

Kepuasan adalah perasaan senang atau kecewa seseorang yang muncul setelah membandingkan kinerja (hasil) produk yang dipikirkan terhadap kinerja atau hasil yang diharapkan (Kotler, 2009). Engel dalam Tjiptono (2005) menyatakan bahwa kepuasan pelanggan merupakan evaluasi purna beli dimana alternatif yang dipilih sekurangkurangnya sama atau melampaui harapan pelanggan, sedangkan ketidakpuasan timbul apabila hasil (outcome) tidak memenuhi harapan. Perbandingan antara harapan dan kinerja yang didapatkan oleh pelanggan akan menghasilkan perasaan senang atau tidak senang

Indikator Kepuasan Pelanggan menurut Hawkins dan Lonney dalam Tjiptono (2001) menyebutkan atribut pembentuk kepuasan terdiri dari:

1. Kesesuaian harapan, yaitu tingkat kesesuaian antara kinerja produk yang diharapkan oleh pelanggan dengan yang dirasakan oleh pelanggan.

2. Minat berkunjung kembali, yaitu kesedian pelanggan untuk berkunjung kembali atau melakukan pembelian ulang terhadap produk terkait

3. Kesediaan merekomendasikan, yaitu kesediaan pelanggan unrtuk merekomendasikan produk yang telah dirasakannya kepada teman atau keluarga.

\section{METODE PENELITIAN}

Penelitian ini dilakukan di Ujenk Mart Bandung pada Juni - Juli 2017. Responden yang diteliti sebanyak 56 dengan penentuan jumlah sampel menggunakan perhitungan iterasi (Hair dkk, 2006). Desain penelitian yang digunakan adalah analisis kuantitatif dengan menggunakan analisis regesi linear sederhana untuk menggambarkan hubungan kausalitas antara dua variabel. Analisis kuantitatif digunakan untuk mengetahu adanya pengaruh nilai pelanggan terhadap kepuasan pelanggan menggunakan regresi linear sederhana. Berikut rumus yang digunakan:

$\mathrm{Y}=a \times b X$

Keterangan:

$\mathrm{Y}=$ Kepuasan pelanggan

$\mathrm{X}=$ Nilai pelanggan

$\mathrm{a}=$ Konstanta regresi sederhana

$\mathrm{b}=$ Koefisien regresi Selanjutnya dilakukan analisis nilai pelanggan yang digunakan untuk mengetahui proposisi produk sayur organik yang dijual di Ujenk Mart. Analisis ini berfungsi untuk mengetahui nilai yang dirasakan dari produk yang ditawarkan. Analisis nilai pelanggan dihitung dengan membandingkan skor keuntungan dengan biaya, lalu menghitung secara keseluruhan dan memposisikan keuntungan produk dan biaya produk dalam customer value mapping. Customer value mapping menampilkan pilihan performa vs harga yang dihadapi pelanggan saat mereka mengevaluasi produk yang ditawarkan.

\section{HASIL PENELITIAN DAN PEMBAHASAN}

\section{Karakteristik Responden}

Berdasarkan hasil analisis dari 56 responden yang membeli sayuran organik di Ujenk Mart, responden sayuran organik di Ujenk Mart mayoritas adalah wanita (71,43\%), rentang umur 26-35 tahun $(42,86 \%)$, berpendidikan s1/ pasca sarjana 
(73,21\%), jumlah anggota keluarga 3-4 orang $(60,71 \%)$, berprofesi sebagai wiraswasta/pengusaha $(26,79 \%)$ dan berpenghasilan rata-rata $\mathrm{Rp} 4.000 .000$ - Rp $6.999 .999(32,14 \%)$. Berdasarkan sebaran demografi responden dapat diketahui bahwa wanita merupakan mayoritas pelanggan yang melakukan pembelian produk sayuran di lokasi penelitian dengan umur rata - rata kategori dewasa dari kelas menengah (middle class). Pengetahuan konsumen berdasarkan kategori pendidikan yang dimiliki dapat dijadikan indikator alasan responden membeli produk sayuran organik yang secara harga lebih mahal dibandingkan sayuran anorgnaik namun dipersepsikan memiliki kualitas produk yang lebih tinggi dengan fokus kepada kesehatan.

\section{Hasil Analisis Nilai Pelanggan}

Pada penelitian ini analisis nilai pelanggan dilakukan di perusahaan Ujenk Mart menggunakan customer value mapping untuk membantu melihat posisi kompetitif produk perusahaan berada di posisi kompetititif yang menguntungkan atau tidak menguntungkan (Gale, 1994). Analisis nilai pelanggan produk sayuran organik di Ujenk Mart akan dilihat dari dimensi nilai kualitas produk yang dapat dilihat pada tabel dan gambar dibawah:

Tabel 1. Analisis Nilai Pelanggan

\begin{tabular}{|c|c|c|c|c|c|c|}
\hline Customer Score Component & Score & $\begin{array}{l}\text { Benefit } \\
\text { Total } \\
\text { Score }\end{array}$ & $\begin{array}{l}\text { Benefit } \\
\text { Average } \\
\text { Score }\end{array}$ & $\begin{array}{l}\text { Cost } \\
\text { Total } \\
\text { Score }\end{array}$ & $\begin{array}{l}\text { Cost } \\
\text { Average } \\
\text { Score }\end{array}$ & $\begin{array}{l}\text { Customer } \\
\text { Value } \\
\text { Score }\end{array}$ \\
\hline \multicolumn{7}{|l|}{ Benefit } \\
\hline 1. Kandungan nutrisi & 344 & & 6.14 & & & \\
\hline 2. Keamanan produk & 337 & & 6.02 & & & \\
\hline 3. Kemasan pelindung produk & 317 & & 5.66 & & & \\
\hline 4. Tampilan produk & 300 & & 5.36 & & & \\
\hline 5. Tampilan kemasan produk & 308 & & 5.50 & & & \\
\hline 6. Keterangan produk & 284 & & 5.07 & & & \\
\hline 7. Ukuran sayuran & 283 & & 5.05 & & & \\
\hline 8. Ketahanan sayuran & 271 & & 4.84 & & & \\
\hline 9. Kerenyahan sayuran & 305 & & 5.45 & & & \\
\hline 10. Bahan kemasan & 240 & & 4.29 & & & \\
\hline 11. Efek kesehatan & 306 & & 5.46 & & & \\
\hline 12. Jaminan logo kemasan & 313 & & 5.59 & & & \\
\hline 13. Bau sayuran & 334 & & 5.96 & & & \\
\hline 14. Daya tahan kemasan & 208 & & 3.71 & & & \\
\hline 15. Daya tahan sayuran & 264 & & 4.71 & & & \\
\hline $\begin{array}{l}\text { 16. Kebersihan tempat } \\
\text { penyimpanan }\end{array}$ & 323 & & 5.77 & & & \\
\hline 17. Akses mencapai sayuran & 295 & & 5.27 & & & \\
\hline 18. Penataan tempat sayuran & 311 & & 5.55 & & & \\
\hline 19. Ketersediaan sayuran & 261 & & 4.66 & & & \\
\hline 20. Kondisi penyimpanan & 306 & & 5.46 & & & \\
\hline 21. Keragaman jenis sayuran & 281 & & 5.02 & & & \\
\hline 22. Warna sayuran & 336 & & 6.00 & & & \\
\hline 23. Rasa sayuran & 291 & & 5.20 & & & \\
\hline 24. Kesegaran sayuran & 320 & & 5.71 & & & \\
\hline
\end{tabular}




\begin{tabular}{|c|c|c|c|c|c|c|}
\hline Customer Score Component & Score & $\begin{array}{l}\text { Benefit } \\
\text { Total } \\
\text { Score }\end{array}$ & $\begin{array}{l}\text { Benefit } \\
\text { Average } \\
\text { Score }\end{array}$ & $\begin{array}{l}\text { Cost } \\
\text { Total } \\
\text { Score }\end{array}$ & $\begin{array}{l}\text { Cost } \\
\text { Average } \\
\text { Score }\end{array}$ & $\begin{array}{l}\text { Customer } \\
\text { Value } \\
\text { Score }\end{array}$ \\
\hline 25. Kebersihan sayuran & 323 & & 5.77 & & & \\
\hline 26. Struktur sayuran & 291 & & 5.20 & & & \\
\hline 27. Keseragaman & 312 & & 5.57 & & & \\
\hline 28. Reputasi brand sayuran & 294 & & 5.25 & & & \\
\hline 29. Reputasi tempat pembelian & 302 & & 5.39 & & & \\
\hline \multirow[t]{2}{*}{ 30. Promosi } & 256 & & 4.57 & & & \\
\hline & & 8916 & 5.31 & & & \\
\hline \multicolumn{7}{|l|}{ Cost } \\
\hline 1. Harga sayur organik di Ujenk & 222 & & & & 3.96 & \\
\hline $\begin{array}{l}\text { 2. Harga sayur yang dibeli } \\
\text { dibanding yang lain }\end{array}$ & 233 & & & & 4.16 & \\
\hline 3. Harga sayur dengan fasilitas & 285 & & & & 5.09 & \\
\hline 4. Jarak & 235 & & & & 4.20 & \\
\hline $\begin{array}{l}\text { 5. Waktu dalam menentukan } \\
\text { pilihan }\end{array}$ & 272 & & & & 4.86 & \\
\hline 6. Waktu dalam mencari produk & 293 & & & & 5.23 & \\
\hline \multirow[t]{2}{*}{ 7. Waktu dalam transaksi } & 304 & & & & 5.43 & \\
\hline & & & & 1844 & 4.70 & 1.13 \\
\hline
\end{tabular}

Sementara itu, hasil analisis nilai pelanggan pada tabel 3 dan customer value mapping pada gambar 1 menunjukkan bahwa nilai keuntungan/benefit yang dirasakan memiliki nilai rata-rata yang tinggi sementara nilai biaya/cost memiliki nilai rata-rata yang lebih rendah. Berdasarkan hasil analisis nilai pelanggan menggunakan customer value mapping yang terlihat pada tabel diatas bahwa produk sayur organik yang di jual di Ujenk Mart berada pada posisi in between/zona antara, dengan dimensi peforma produk sebagai pengaruh atas nilai yang dirasakan pelanggan masuk kedalam kategori performa superior, dan nilai harga atau cost yang dikeluar harus lebih tinggi pula. Hasil skor tersebut dapat dilihat berdasarkan dari nilai kualitas produk yang diambil dari dimensi kualitas. Analisis deskriptif memberikan makna bahwa konsumen dapat merasakan manfaat lebih dari sayuran organic

\section{Hasil Analisis Regresi Linear}

Penelitian ini mengambil sampel sebanyak 56 responden yang dilakukan pada bulan Juli 2017. Hasil analsiis regresi selanjutnya ditampilkan sebagai berikut: berdasarkan kualitas produk yang dimilikinya, namun secara serta merta harus mengeluarkan biaya lebh untuk dapat mengkonsumsi produk sayuran organik. Sehingga, konsep customer centricity yaitu strategi pemasaran dengan fokus kepada konsumen (customer orientation) merupakan salah satu upaya untuk meningkatkan kepuasan pelanggan melalui penciptaan nilai pelanggan yang superior (Gummesson, 2008).

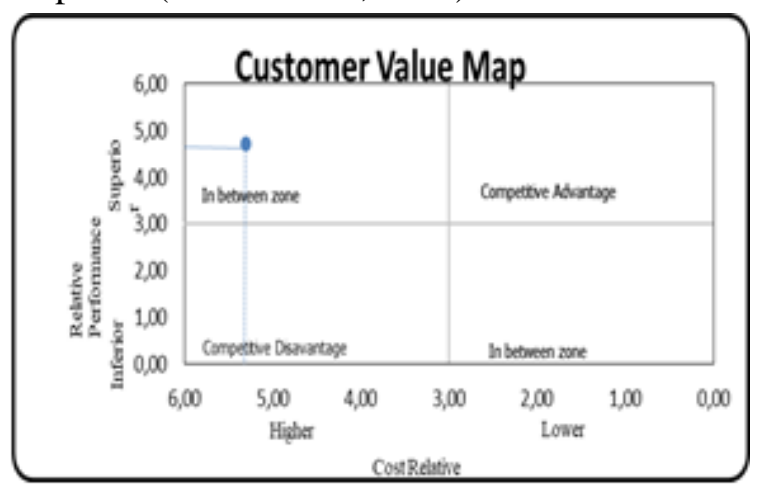

Gambar 1. Customer Value Mapping 


\section{Koefisien Determinasi (R Square)}

Pengujian koefisien determinasi

dilakukan untuk mengukur seberapa

jauhkemampuan model regresi dalam

Tabel 2. Hasil Perhitungan Koefisien

Determenasi R Square

\begin{tabular}{llllll}
\hline Model & $\mathbf{R}$ & $\begin{array}{l}\mathbf{R} \\
\text { Sqaure }\end{array}$ & $\begin{array}{l}\text { Adjusted } \\
\mathbf{R}\end{array}$ & $\begin{array}{l}\text { Std. } \\
\text { Error of } \\
\text { the } \\
\text { Estimate }\end{array}$ & $\begin{array}{l}\text { Durbin- } \\
\text { Watson }\end{array}$ \\
\hline 1 &, $574^{\mathrm{a}}$ &, 329 &, 317 & 4,39175 & 1,983 \\
\hline
\end{tabular}

a. Predictors: (constant), Nilai Pelanggan

b. Dependent Variable: Kepuasan Pelanggan

Sumber: data diolah, 2017

dapat dilihat bahwa nilai R Square adalah

0,329, jadi dapat disimpulkan bahwa 32,9\%

variabel kepuasan pelanggan dapat

diterangkan oleh variabelnilai pelanggan.

Sedangkan sisanya sebesar $67,1 \%$ diterangkan oleh variabel lain yang tidak diteliti dalam penelitian ini.

\section{Pengujian Secara Overall (F Hitung)}

Hipotesis yang penulis ajukan untuk penelitian ini adalah :

$H_{0}$ : Tidak terdapat pengaruh yang signifikan dari nilai pelanggan berdasarkan kualitas produk terhadap kepuasan pelanggan.

$H_{l}$ : $\quad$ Terdapat pengaruh yang signifikan dari nilai pelanggan berdasarkan kualiats produk terhadap kepuasan pelanggan.

Tabel 3. Hasil Uji Statistik F (ANOVA)

\begin{tabular}{llll}
\hline \multicolumn{1}{l}{ Model } & Sum of Squares & df \\
\hline 1 & Regression & 511,342 & 1 \\
& Residual & 10141,525 & 5 \\
& Total & 1552,867 & 55
\end{tabular}

Sumber: data diolah, 2017

Dari tabel di atas dapat dilihat nilai $\mathrm{F}$ hitung adalah sebesar 26,512 dengan nilai signifikansi F sebesar 0,000. Pengujian akan menolak Ho jika $p$-value $<\alpha$. Jika dibandingkan dengan taraf signifikan $\alpha=5 \%$ maka p-value $(0,000)$ bernilai lebih kecil dari $\alpha$ sehingga $\mathrm{H}_{0}$ ditolak dan $\mathrm{H}_{1}$ diterima. Jadi, terdapat pengaruh yang signifikan dari nilai pelanggan terhadap kepuasan pelanggan. menerangkan variasi variabel dependen.

Besaran R Square digunakan untuk mengukur goodness of fits garis regresi.

Tabel di atas merupakan hasil dari pengujian koefisien determinasi. Dari tabel tersebut

\begin{tabular}{|c|c|c|c|c|c|}
\hline \multicolumn{6}{|c|}{$\begin{array}{l}\text { Pengujian Signifikansi Paramete } \\
\text { Individual (Uji Statistik t) } \\
\text { Tabel 4. Hasil Uji-t Statistik }\end{array}$} \\
\hline \multirow{2}{*}{ Model } & \multicolumn{2}{|c|}{$\begin{array}{l}\text { Unstandardize } \\
\text { d Coeffients }\end{array}$} & \multirow{2}{*}{$\begin{array}{l}\text { Stan } \\
\text { dard } \\
\text { ized } \\
\text { Coef } \\
\text { ficen } \\
\text { ts } \\
\text { Beta }\end{array}$} & \multirow{2}{*}{$\mathbf{t}$} & \multirow{2}{*}{ Sig. } \\
\hline & B & $\begin{array}{l}\text { Std. } \\
\text { Error }\end{array}$ & & & \\
\hline $\begin{array}{l}\text { (Constant) } \\
\text { Nilai } \\
\text { Pelanggan }\end{array}$ & $\begin{array}{l}3,488 \\
, 182\end{array}$ & $\begin{array}{l}5,906 \\
, 035\end{array}$ & ,574 & $\begin{array}{l}, 591 \\
5,149\end{array}$ & $\begin{array}{l}, 557 \\
, 000\end{array}$ \\
\hline
\end{tabular}

a. Dependent Variable: Kepuasan Pelanggan

Sumber: data diolah, 2017

Dari tabel tersebut maka diperoleh nilai parameter konstanta dan nilai parameter penduga untuk melengkapi model regresi

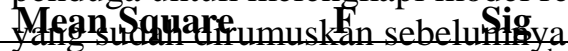

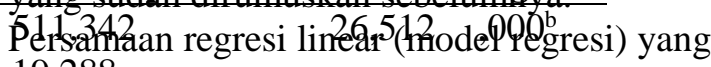
terbefpuk adalah sebagai berikut : $\mathrm{Y}=3,488+0,182 \mathrm{X}$

Pada persamaan di atas, koefisien intersep sebesar 3,488 menunjukkan besarnya kepuasan pelanggan tanpa pengaruh nilai pelanggan. Koefisien regresi untuk X sebesar 0,182 menunjukkan setiap peningkatan 1 satuan nilai pelanggan maka akan menaikan kepuasan pelanggan sebesar 0,182.

Berdasarkan uji signifikansi pada tabel diatas diperoleh nilai t hitung sebesar 5,149> ttabel $(2,004)$ sehingga Ho ditolak dan $\mathrm{H}_{1}$ diterima, atau dapat disimpulkan bahwa nilai pelangan mempunyai pengaruh secara signifikan terhadap kepuasan pelanggan. Hal ini didukung oleh penelitian Shoki (2012) bahwa nilai pelanggan berpengaruh positif secara signifikan terhadap kepuasan konsumen. 
Sehingga dapat dikatakan bahwa nilai pelanggan yang dilihat atas nilai kualitas produk sayuran organik di Ujenk Mart dapat memberikan kepuasan terhadap pelanggan.

\section{Keterbatasan dan Agenda Penelitian Mendatang}

Penelitian ini hanya menggunakan dimensi kualitas produk dalam mengukur nilai pelanggan, namun upaya pemasaran lain yang dapat digunakan untuk mengukur kepuasan pelanggan tidak diikutsertakan untuk melihat kepuasan pelanggan yang melakukan pembelian produk sayuran segar organik di saluran pemasaran seperti specialty store. Sehingga pada penelitian berikutnya dapat dikembangkan lagi dengan mengukur kepuasan pelanggan khusus untuk produk segar dengan memasukkan variable lain yang digunakan dalam dimensi strategi pemasaran sebagai upaya meningkatkan nilai yang diterima oleh pelanggan secara lebih komprehensif. Kontribusi dari berbagai faktor yang diikutsertakan dalam analisis empirik dapat memberikan pemahaman yang lebih luas mengenai nilai pelanggan untuk produk produk agribisnis yang dipasarakan di saluran pemasaran modern.

\section{KESIMPULAN}

Proposisi nilai pelanggan dari produk sayuran organik di Ujenk Mart berada pada zona-antara dimana produk ini dinilai sebagai fair-value yang berarti manfaat yang diterima konsumen atas pembelian produk setimpal dengan total biaya yang harus dikeluarkan baik secara biaya materil maupun imateril. Hal ini menunjukkan bahwa produk sayuran organik yang dijual di Ujenk Mart belum memiliki keunggulan bersaing yang kompetitif, sehingga jika tidak mampu meningkatkan nilai yang diterima konsumen atau bahkan mempertahankannya maka nilai pelanggan atas kualitas produk sayuran organic yang dijual akan dianggap tidak memiliki keunggulan bersaing. Nilai pelanggan atas kualitas produk sayuran organik memiliki pengaruh signifikan terhadap kepuasan pelanggan Agar memiliki keunggulan bersaing di pasar maka perlu adanya kombinasi program pemasaran yang dilakukan untuk dapat meningkatkan kepuasan pelanggan atas pembelian sayuran organik. Hal ini sejalan dengan konsep nilai yang tidak dapat dipisahkan dari makna kualitas bagi konsumen dan satu sama lain memiliki konstruk yang sama sabagai ukuran persepsi konsumen atas ukuran keseimbangan manfaat (kepantasan) dan kegunaan (Zeithaml, 1988). Namun, menciptakan nilai pelanggan yang lebih unggul dibandingkan pesaing membutuhkan upaya untuk mengharmoniskan antara pemahaman pemasar dan konsumen mengenai konsep nilai di dalam memasarkan produk

(Gummesson, 2008).

\section{DAFTAR PUSTAKA}

Christopher, M dan Peck, H. (1997). Marketing Logistic, Oxford: Butterworth Heinemann.

Gale, B.T., \& Wood, Robert. (1994). Managing Customer Value: Creating Quality and Service That Customer Can See, New York: The Free Press.

Gummesson, E. (2008). Customer centricity: reality or a wild goose chase?, European Business Review, 20(4), 315-330.

Hair, J.F., W.C. Black, B.J. Babin, R.E. Anderson, R.L.Tatham. (2006). Multivariate Data Analysis sixth Edition, New Jersey: Prentice Hall.

Kotler, Philip. (2000). Manajemen Pemasaran Jilid 1, Jakarta: PT. Prenhallindo.

Kotler, Philip dan Keller. (2009). Manajemen Pemasaran Edisi 12 Jilid 1, Jakarta: Indeks.

Lusk, J.L. (2011). External validity of the food values scale, Food Quality and Preference, 22, 452-462.

Mainieri, T., Barnett, E., Valdero, T., Unipan J, and Oskamp, S. (1997). Green buying: the influence of environmental concern on cutomer buying, Journal of Social Psychology, 137(2), 189-204.

Pracaya. (2006). Bertanam Sayuran Organik Cetakan Keenam, Jakarta: Penebar Swadaya.

Sweeney, J. C. dan Soutar, G. N. (2001). Consumer perceived value: the development of a multiple item scale, Journal of Retailing, 77, 203-220.

Tjiptono, Fandy. (2001). Strategi Pemasaran, Yogyakarta: Andi.

Tjiptono, Fandy. (2005). Total Quality Service (TQS), Yogyakarta: Andi. 
Utami, H.N., Sadeli, A.H., Perdana, Tomy. (2016). Customer Value Creation of Fresh Tomatoes through Branding and Packaging as Customer Perceived Quality, International Society for Southeast Asian Agricultural Sciences - Philippines, 22, 123-136.

Vargo, S. L., and Lusch, R. F. (2008).

Service-dominant logic: continuing the evolution, Journal of The Academic Marketing Sciences, 36, 1-10.

Woodruff, Robert B. (1997). Customer Value: The Next Source for Competitive Advantage, Journal of Academy of marketing Science, 25(2), 139-153.

Zeithaml, V. A., (1988). Consumer Perceptions of Price, Quality, and Value: A Means-End Model and Synthesis of Evidence, Journal of Marketing, 52(3), 37-64. 
Vol. 3, No. 1, Juli 2018: 359-426

AGRICORE:Jurnal Agribisnis dan Sosial Ekonomi Pertanian 